\title{
THE ROLE OF BOTANIC AND ZOOLOGICAL GARDENS IN NATIONAL CONSERVATION PLANNING
}

\author{
H B RYCROFT
}

Director: National Botanic Gardens of South Africa

Kirstenbosch

Claremont

Cape

7735

I am to talk about botanic and zoological gardens and the role they play, or should play, in the conservation of our wild life in its broadest sense.

To get everything straight, let us see in the first place what we mean by a botanic and a zoological garden. The simplest definition of a botanic garden is that of the International Directory of Botanic Gardens (2nd Ed. Fletcher, Henderson, and Prentice) which simply requires a garden to be open to the public and in which the plants are labelled. C S Gager, a former Director of the Brooklyn Botanical Garden, New York, defined and described a botanic garden as: "Originally a garden with the plants arranged according to some system of botanical classification. A botanic garden is properly defined as a scientific and educational institution, whose purpose is the advancement and diffusion of a knowledge and love of plants. Modern gardens usually possess living collections, herbaria, library, experimental gardens for plant breeding, laboratories, lecture halls and in some cases, botanical museums, together with scientific, educational and administrative staffs."

The ideal of the National Botanic Gardens of South Africa is primarily an authenticated living collection of indigenous plants, cultivated in gardens. Material and facilities for research are provided, knowledge is disseminated to scientists and the general public and visitors are made aware of this floral heritage and encouraged to conserve the South African flora. The broad policy of the institution is scientific and educational and it is concerned with the cultivation, display, scientific study and conservation of the native flora of the Republic of South Africa, through its efforts and activities, both in the gardens and in the country generally.

Zoological gardens can be defined in vaguely similar terms, the accent of course being on animals, although plants also play a very significant role in zoos.

Whatever planning is undertaken for the conservation of our natural resources or any other resource for the benefit of man, the role of plants 
is paramount. Plants, it must be remembered, form the basis of all animal life, including that of man himself. Without plants, without vegetation, without green organisms, there can be no animals.

We are aware that the ultimate source of all energy on our planet earth, is the sun, and that the principal means by which this energy is harnessed is through plants. Approximately $0,1 \%$ of the solar energy which reaches us, is fixed by the wonderful and still incompletely understood process of photosynthesis. This fraction, small as it is, results in the production on a world-wide basis, of between 150 and 200 thousand million (150000 000 000-200000 000 000) tons of dry organic matter every year. The rapid, even frightening, increase in human population requires simply that an ever larger fraction of the energy fixed by plant life be diverted to the support of a single species - man himself. The long-term trend of evolution towards building up complex, integrated, stable ecosystems is being reversed before our very eyes, with consequences which we can but dimly foresee, or perhaps fear to anticipate.

Man in his efforts to increase his own food supply and to provide living space, resorts to the destruction of natural ecosystems and their replacement with artificial ones and with deserts of concrete, brick, mortar and plastics. The veld is being cleared to make way for biologically sterile industry, townships and sprawling cities connected by equally barren networks of roads and railways. Another more forbidding effect of man's activities is that an ever-increasing fraction of the earth's surface is being withdrawn, wholly or partially, from energy fixation as a result of building development and soil deterioration through exhaustion or erosion.

The plant life on which we all ultimately depend for our very existence, is being threatened, not only on land but also in lakes and in the oceans. It is imperative that measures be found to halt, and, if possible, to reverse this trend. Clearly, research on plants, their metabolism, their ecological relationships and the maintenance of a healthy vegetation cover have become matters of vital necessity to the human race. Upon their successful application, man's continuing dominance of the biosphere may ultimately depend.

Several general principles apply equally to botanic and to zoological gardens. The benefits flowing from them can be comparable and, in this respect, I consider particularly (i) Public Service, (ii) Education, (iii) Research and (iv) Conservation. (J K Moore: Botanic Gardens and Arboreta). These various aspects are closely interlinked, but can be viewed separately.

(i) Public Service. Let us be clear about this in our own minds. Gardens and zoos are established and maintained largely because the man in the street, the general public, you and I want them for the joy of having them. The scientific, educational and cultural benefits, most important 
though they may be, are not always the main reasons why we have these establishments. Gardens of both types offer social, cultural, economic, recreational and aesthetic facilities.

(ii) Education. Many gardens are adjunct to, or actual parts of, educational institutions. As such the organisation provides courses, programmes or facilities in plant- and/or animal-related subjects, varying from formal graduate level courses to popular one-day study excursions.

These may be:

(a) graduate and undergraduate level biology, botany, horticulture and zoology;

(b) short courses and workshops on many phases of plant and animal study for the general public and professionals from other disciplines;

(c) nature study programmes for school groups;

(d) environmental awareness programmes for groups from pre-school age to retired persons;

(e) special workshops for teachers of natural sciences; and

(f) classes and demonstrations for professional botanists, horticulturists and zoologists.

(iii) Conservation. With the increased pressure of population and development upsetting or destroying natural areas, gardens are in a position of public and political influence not yet fully realised or exploited.

They can play a significant role by:

(a) acquisition of natural areas;

(b) planting of representative native plants, cultivation of rare and endangered species of plants, breeding of rare and endangered species of animals and preserving portions of the garden estate in their natural state;

(c) various courses offered to the public, which stress the importance of natural areas;

(d) preservation of various ornamental forms and varieties of plants which may be neglected by nurseries; and

(e) co-operative efforts with other conservation groups to lobby for particular legislation or governmental protection.

(iv) Research. The field of research which can be undertaken is almost limitless. Gardens should have the unique advantage of offering indoor laboratory facilities similar to those in most universities and research establishments and, in addition, field conditions to supplement such facilities.

In planning conservation on a national basis, gardens and zoos do not provide the ultimate goal or aim in the broadest sense because they present only a fraction or small sample of the whole, in what might be not completely natural conditions. They do, however, provide the essential stepping stones towards the realisation of the most desirable conservation ideals. 
The individual ecological components must be studied and understood before the total mosaic of the ecosystem can be tackled. For example, the autecology of as many species as possible, both plant and animal, must be investigated. This type of work can be largely undertaken in botanic gardens and zoos, where adequate facilities are available. In building up the mosaic it is essential to call in the assistance and co-operation of disciplines in philosophies other than biology, such as those of the engineer, town planner, geologist, sociologist, meteorologist, economist and even the politician. Let's face it, the last named can either make or break any conservation plan or programme!

In many instances, the best way to preserve a species is to preserve the habitat in which it occurs naturally. We must decide, however, whether we wish to preserve an individual species or specified number of species or whether we think it desirable to preserve or conserve the community in its entirety. If the latter is the case, we must further decide in what particular condition the community or ecosystem must be maintained. Is it the climax condition where we understand that all the species of both the plant and animal kingdom exist and will continue to exist in perfect and stable equilibrium, or is it some seral stage of the succession which can be maintained at that level only by special treatment, manipulation and management?

Botanic and zoological gardens can provide the facilities for much of the research that is required in attempting to make the decisions and to find the answers. 